\title{
Újraélesztést követő koszorúér-angiográfia és katéteres intervenció
}

\author{
Rudas László dr. ${ }^{1}$ - Zima Endre dr. ${ }^{2}$ \\ 'Szegedi Tudományegyetem, Általános Orvostudományi Kar, \\ Aneszteziológiai és Intenzív Terápiás Intézet, Szeged \\ ${ }^{2}$ Semmelweis Egyetem, Általános Orvostudományi Kar, Városmajori Szív- és Érgyógyászati Klinika, Budapest
}

\begin{abstract}
A kórházon kívüli hirtelen szívhalál a világ fejlett országaiban jelenleg is nagy kihívást jelent. Erőfeszítéseink elsősorban az ellátás prehospitális szakaszára irányulnak, hiszen az itt nyújtott segítség előnyeit utóbb már semmi sem pótolhatja. Igyekszünk felvilágosító munkával növelni a laikus újraélesztés arányát, növelni a közterületi automata defibrillátorok számát, megkönnyíteni azok elérhetőségét. Az utóbbi időben a kórházi fázisban történő ellátás jelentőségét is egyre inkább felismerjük. A postresuscitatiós ellátásban a hőmérsékletkontroll mellett az egyik legfontosabb kulcspont a korai koronarográfia, illetve szükség esetén a katéteres intervenció. A primer koronarográfia és intervenció indikációja egyértelmú azon betegeknél, akiknek az újraélesztés után készült EKG-felvételén ST-eleváció látható. Számukra közvetlen utat kell biztosítani a katéteres laboratóriumok felé. A nem ST-elevációs alcsoport optimális ellátása még tisztázásra vár. Tény, hogy közülük is minden harmadiknál, negyediknél számíthatunk okkluzív epicardialis koszorúér-betegségre, ennél az alcsoportnál azonban még nem bizonyított, hogy a közvetlen út a katéteres laboratóriumba milyen módon befolyásolja a későbbi kilátásokat. Jelenleg számos tanulmány folyik a témában, összefoglalónkban ezeket a forrongó kérdéseket mutatjuk be.
\end{abstract}

Orv Hetil. 2019; 160(46): 1826-1831.

Kulcsszavak: kórházon kívüli hirtelen szívhalál, postresuscitatiós ellátás, sürgősségi koszorúér-angiográfia

\section{Coronary angiography and percutaneous intervention after resuscitation}

Out-of-hospital cardiac arrest (OHCA) presents a great challenge for the health care systems even in the highly developed countries. For several decades, our greatest efforts have been directed toward the improvement of the prehospital management, including promotion of lay resuscitation and deployment of public access automated defibrillators. Recently, the importance of the hospital phase of the OHCA-management has been also emphasized. Attention has been paid to targeted temperature management and also to early coronary intervention. For those patients who present with ST-elevation on their post-resuscitation ECG, our approach is straightforward: urgent coronary angiography is indicated. The optimal management of those survivors of OHCA who present without ST-elevation is, however, still debated. Although up to $30 \%$ of these subjects also suffer from acute occlusive epicardial coronary disease, the clear benefit of urgent coronary angiography for the whole group is yet to be documented. Several largescale randomized studies are under way to resolve this question. In our present review we detail the above controversies and outline the future directions.

Keywords: out-of-hospital cardiac arrest, post-resuscitation management, urgent coronary angiography

Rudas L, Zima E. [Coronary angiography and percutaneous intervention after resuscitation]. Orv Hetil. 2019; 160(46): 1826-1831.

(Beérkezett: 2019. július 21.; elfogadva: 2019. szeptember 18.) 


\section{Rövidítések}

$\mathrm{CAG}=$ (coronary angiography) koszorúér-angiográfia; CAHP $=($ Cardiac Arrest Hospital Prognosis $)$ A keringésmegállás kórházi prognózisa; COACT $=$ (Coronary Angiography After Cardiac Arrest) Szívkoszorúér-angiográfia szívmegállás után; COUPE $=$ (Coronariography in OUt of hosPital cardiac arrEst) kórházon kívüli szívmegállást követő coronaria angiográfia; DISCO = (DIrect or Subacute Coronary angiography in Out-of-hospital cardiac arrest study) Direkt vagy szubakut coronariaangiográfia a kórházon kívüli szívmegállásban; EAPCI $=($ European Association of Percutaneous Cardiovascular Interventions) Európai Perkután Katéteres Intervenciós Szövetség; EKG = elektrokardiográfia $;$ INTCAR = (International Cardiac Arrest Registry) Nemzetközi Hirtelen Szívhalál Regiszter; OHCA = (out-of-hospital cardiac arrest) kórházon kívüli szívmegállás; $\mathrm{PCI}=$ (percutaneous coronary intervention) perkután coronariabeavatkozás; PROCAT = $($ Parisian Registry Out-of-Hospital Cardiac Arrest) Párizsi Régió Hirtelen Szívhalál Regiszter; ROC = (Resuscitation Outcomes Consortium) Újraélesztés Kimenetelét Kutató Hálózat; ROSC = (return of spontaneous circulation) a spontán keringés visszatérése; STEMI = (ST-elevation myocardial infarction) ST-elevációval járó myocardialis infarctus

A hirtelen szívhalál, melyet a szív funkcionális mechanikus aktivitásának hirtelen megszűnéseként értelmezünk, napjainkban is gyakori jelenség; sôt, a világ fejlett országaiban növekvő tendenciát mutat [1]. Becslések szerint az Egyesült Államokban évi 235 000-350 000 embert, Európában pedig ugyancsak évi 275 000-350 000 embert érint a kórházon kívüli hirtelen szívhalál (OHCA) [1-3]. Az OHCA túlélési esélyei hosszú évtizedekig változatlanok maradtak, és megerósítést nyert az is, hogy a túlélésért folytatott küzdelem elsősorban a prehospitális fázisban dől el [4]. A túlélésben mutatkozó regionális különbségeket ugyancsak a prehospitális faktorokon keresztül értelmeztük, mint például a szemtanú jelenlétének esélye, a mentő gyors helyszínre érkezésének lehetősége, a közösségi automata defibrillátorok elérhetősége vagy a laikus újraélesztési hajlandóság országok, területek közt tapasztalható különbségei [4]. A földrajzi vagy a szociális adottságok természetesen nem vagy csak nagyon nehezen befolyásolhatók, de jelenleg is óriási erôfeszítések irányulnak a módosítható tényező́k minőségének, hatékonyságának javítására. Megállapítható, hogy a legutóbbi időkben beindult egy lassú változás, különbözô források minimálisan javuló OHCA-túlélési mutatókról számoltak be. Így például Daya és mtsai 2015-ben a nagy észak-amerikai kutatószervezet, a Resuscitation Outcomes Consortium (ROC) adataira támaszkodva közölték, hogy az OHCA kórházi túlélése a 2006-os 8,2\%-ról 2010-re 10,4\%-ra nőttt [5]. Könnyú lenne a jelenséget azzal elintézni, hogy a javulás a világ legfejlettebb országaiban a prehospitális ellátás javulásával függ össze, tudjuk azonban, hogy a kórházi fázisban történtek szintén befolyásolják a kimenetelt. Stub és mtsai ugyancsak a ROC-adatbázisra támaszkodva 2015-ben olyan analízist közöltek, melyben a kutatásban részt vevő kór- házakat a postresuscitatiós ellátás jellemzői alapján csoportosították [6]. Olyan indikátorokat választottak, melyek alapján megítélhetó volt, hogy az egyes kórházak mennyire követték az aktuális vezérfonál postresuscitatiós hốmérsékletkontrollra, illetve koronarográfiára irányuló ajánlásait, $s$ a pontszámok alapján négy negyedbe osztották a résztvevő́ket. A kórházi kibocsátás, illetve a kedvező neurológiai kimenetel aránya a leginkább szabálykövető alcsoportban közel kétszeres volt a legkevésbé szabálykövető kórházak eredményéhez képest [6]. Ezt az előnyt természetesen nem lehet teljes egészében a hútés vagy a katéteres intervenció hatásának tulajdonítani. Feltételezhető, hogy a legmagasabb pontszámot elérő kórházakban a postresuscitatiós ajánlások más, az adott vizsgálatban nem ellenőrzött elemeit, továbbá az orvosi ellátás egyéb általános szabályait („good medical practice") is pontosabban követték, s minden bizonnyal ezek is hozzájárultak a kedvező kimenetelhez. Mindenesetre bebizonyosodni látszik, hogy a kórházi ellátási fázisra fokozottan kell figyelnünk, és a minőségi indikátorként is használt beavatkozások, ha nem kizárólagos jelentôségúek is, de nagyon fontosak.

A hőmérsékletkontroll tekintetében számos megválaszolatlan kérdésünk van. Nem teljesen tisztázott az optimális célhőmérséklet, és jelenleg is kutatások tárgya, hogy a hưtéshez használt eszközöknek milyen szerepük lehet a kimenetelben [7]. A kérdést a jelen összefoglalóhoz csatlakozó társközlemény részletesen tárgyalja.

A postresuscitatiós fázisban elvégzett koronarográfia (CAG) és katéteres intervenció (PCI) vonatkozásában ugyancsak akadnak nyitott kérdések. Egyszerúbben megtervezhetô a tevékenységünk, ha a sikeres újraélesztést követően elkészült EKG-felvételen ST-elevációt regisztrálunk; ez a prezentáció leegyszerúsítve a STEMI hirtelen szívhalállal szövődő eseteként is értelmezhető. Tudjuk mindazonáltal, hogy ebben a helyzetben az STeleváció jelenléte más jelentőséggel bír, mint az újraélesztéssel nem járó esetekben. Ismert módon átmeneti ST-mozgást (elevációt) okozhat maga az elektromos defibrilláció [8] és az újraélesztést követően gyakran észlelhetô elektrolitzavarok [9]. Hirtelen szívhalálhoz vezethet a subarachnoidealis vérzés, mely ugyancsak ST-elevációs EKG-képpel járhat [10]. Mindezekkel a limitációkkal együtt friss közlemények sora is egybehangzóan igazolja, hogy az ST-elevációs postresuscitatiós esetek mintegy $80-90 \%$-ában a CAG okkluzív epicardialis koszorúér-betegséget igazol [11-13]. Ez a rendkívül magas arány minden kétséget kizáróan bizonyítja, hogy e betegek számára indokolt az egyéb STEMI-esetekkel analóg ellátás, a kerülőmentes út a szívkatéteres laboratórium felé. Reanimált STEMI-s betegek katéteres intervencióval végzett kezeléséről elsőként Kabn és mtsai közöltek beszámolót 1995-ben [14]. A cikkben 11, kamrafibrillációból újraélesztett beteg PCI-terápiájáról írtak. Ezt követően a közlemények száma gyorsan szaporodott. A helyzet különösen egyértelmúvé vált azon betegeknél, akiknél a nagyon gyors újraélesztés nyomán a 
tudat már a katéteres beavatkozás előtt visszatért. Tisztázódott, hogy e betegek túlélési esélyei katéteres intervenciós kezeléssel megegyeztek a hirtelen szívhalált el nem szenvedő STEMI-s betegekéivel [15]. A komatózus túlélők túlélési esélyei természetesen rosszabbak ennél, a beavatkozás azonban számukra is előnyt biztosít [15]. Napjaink vezérfonalai valamennyi ST-elevációs újraélesztett beteg számára, a tudatállapottól függetlenül, a legerősebb szintű ajánlással írják elő a koronarográfiát [16].

Sokkal kevésbé egyértelmű a helyzet a nem ST-elevációs alcsoportban. A hirtelen halál e betegek közt lehet nem cardialis, illetve nem ischaemiás eredetű, továbbá koszorúér-betegségük (ha fennáll) lehet krónikus jellegú. Az akut okkluzív epicardialis laesio gyakorisága lényegesen alacsonyabb, mint az ST-elevációs populációban. Radsel és mtsai nem ST-elevációval újraélesztett szlovén betegek 2003 és 2008 közti katéterezésével 24\%-ban igazoltak obstruktív koszorúér-laesiót [17]. Hollenbeck 2014-es közleményében e csoportban az akut koszorúér-okklúzió 27\%-ban fordult elő [18]. Kern és mtsai az "International Cardiac Arrest Registry" (INTCAR) adatainak retrospektív elemzésével a nem ST-elevációs esetek 33\%-ában igazoltak culprit laesiót, s ezek 69\%-a volt okkludált [19]. Dumas és mtsai a PROCAT II regiszter adatai alapján azt találták, hogy a betegek $29 \%$-ában volt olyan culprit laesio, mely a hirtelen szívhalálért felelős lehetett [20]. Elfwén és mtsai 2018-as közleményében sokkolható ritmussal resuscitatióban részesített betegek ST-eleváció nélküli csoportjában ugyancsak 27\%-ban előforduló koszorúér-okklúzió szerepel [21]. Millin és mtsai 11 közleményt feldolgozó metaanalízise szerint a nem ST-elevációs betegek 32\%ában fordul elő intervenciót igénylő culprit laesio [22]. Nagy általánosságban elmondható, hogy az ST-eleváció nélküli alcsoportban minden harmadik-negyedik betegnél számíthatunk akutan elzáródott vagy kritikus szúkülettel bíró epicardialis érágra. ( $\mathrm{Ne}$ feledkezzünk meg azonban arról, hogy a fenti vizsgálatokban, illetve regiszterekben a nem ST-elevációs betegek többnyire valamilyen előszelekciót követően érkeztek katéterezésre.) $\mathrm{Az}$ adatok mindenesetre megerósítik azt a korábban is ismert tényt, hogy az ST-eleváció hiánya nem zárja ki az epicardialis ér okklúzióját, illetve kritikus szúkületét. E betegeknél az anamnézis, a keringés-összeomlást megelőző tünetek, illetve a kollapszus körülményei utalhatnának a koszorúér-elzáródásra. Mint tudjuk, ezek az információk gyakran teljesen hiányoznak, s a gyakorlatban ritkán tudunk ezekre hagyatkozni. Pillanatnyilag nincs teljes egyetértés a resuscitatióban részesített nem ST-elevációs betegek katéterezését illetően. Az Európai Perkután Katéteres Intervenciós Szövetség (EAPCI) 2014-es ajánlásában azt javasolta, hogy e betegeket lehetôség szerint 2 órán belül a katéteres laboratóriumba kell juttatni (a köztes idő szolgálna a fontosabb alternatív kórokok kizárására) [23]. Az Európai Resuscitatiós Tanács és az Európai Intenzív Terápiás Társaság 2015-ös közös ajánlása óvatosabban fogalmaz: hangsúlyozzák, hogy nem minden centrum ért egyet a fenti szoros időablakon belül végzett katéterezéssel [16]. Az ellentmondások háttere összetett. A legfontosabb problémánk, hogy a nem ST-elevációs, resuscitatióban részesített betegeknél végzett koszorúér-angiográfia, illetve intervenció hasznát közlő tanulmányok szinte kivétel nélkül obszervációs, zömmel retrospektív vizsgálatok voltak [18, 19, 24, 25]. Az egyetlen publikált, randomizált kontrollált vizsgálat mind ez ideig az „ARREST pilot trial” volt, mely kis esetszáma miatt következtetésekre még nem alkalmas [26]. Az összes többi, mégoly meggyőző eredményű vizsgálat is hagy nyitott kérdéseket. A retrospektív vizsgálatok nagy buktatója a szelekciós hiba. A vizsgálatokból rendre kiderül, hogy a korai intervencióban részesülő, illetve nem részesülő betegek eltértek egymástól az életkor, a társbetegségek, illetve a szívelégtelenség tekintetében. Jól igazolja a fenti aggályokat Vadeboncoeur és mtsai frissen publikált közleménye [27]. Nagy arizonai beteganyagot vizsgálva azt találták, hogy a nem ST-elevációs, resuscitatióban részesített betegek csoportján belül a koronarográfiában nem részesülők túlélése $56 \%$ volt, a koronarográfiával vizsgált, de koszorúér-intervencióban nem részesülők túlélése pedig $82 \%$ - praktikusan megegyező az intervencióval kezeltekével [27]. Senki sem tételezheti fel, hogy a koszorúér-angiográfia önmagában jótékony hatású. A koronarográfia esélye a vizsgálatban összefüggött a szemtanú által látott keringés-összeomlással, a sokkolható iniciális ritmussal és a kiegészítő kezelésként alkalmazott hütéssel is. Ezek a különbségek önmagukban meghatározhatták a kimenetelt [27]. Pillanatnyilag az ST-elevációt mutató betegek esélye arra, hogy sürgősséggel a katéteres laborba jussanak, a nem ST-elevációs betegekének a 13-szorosa [22]. A rendkívüli bizonytalanság miatt időszerú, hogy végre nagy prospektív randomizált vizsgálatok alapján adjunk választ a kérdésre. Pillanatnyilag több ilyen vizsgálat is zajlik a világban. A Hollandiában zajló COACT-vizsgálat az azonnali ( 2 órán belüli) és a halasztott koronarográfiás megközelítést hasonlítja össze, a végpont a 90 napos túlélés [28]. A PEARL trial, az Egyesült Államokban zajló multicentrikus vizsgálat ugyancsak a 120 percen belüli, illetve a halasztott angiográfia kimenetelét hasonlítja össze [29]. A Németországban zajló TOMAHAWKvizsgálatban az egyik szárnyon a betegeket azonnal a katéteres laboratóriumba viszik, a másik szárnyon a jelenlegi rutinszerü ellátást folytatják [30]. A Franciaországban szervezett EMERGE-vizsgálatban a mentőszolgálat végzi a randomizációt, és az előzőhöz nagyon hasonló ellátási szárnyakat alakítanak ki [31]. Még érdekesebb a Skandináviában folyó DISCO trial elrendezése. Az egyik szárnyon a betegek azonnali ( 2 órán belüli) katéterezésre kerülnek, a másik szárnyon pedig - hacsak a betegek állapota mást nem követel - három nap halasztással végzik el a vizsgálatot [32]. Ugyancsak a korai és a halasztott, azaz a kibocsátás előtt elvégzett koszorúér-angiográfia hatását tervezik összehasonlítani a COUPE-vizsgálatban [33]. Az ARREST-vizsgálat, melynek 'pilot trial'-ét már 
említettük, randomizált módon azt vizsgálja, hogy a hirtelen szívhalál ellátására kialakított speciális centrumokba történő szállítás, illetve az ott megtörténő CAG/PCI miként befolyásolja a nem ST-elevációs újraélesztett betegek sorsát [26].

Mindezek alapján megjósolható, hogy az újraélesztés nem-ST-elevációs túlélőinek ellátásáról a közeli jövőben egyértelmú bizonyítékok állnak majd rendelkezésünkre. Paradox módon az ST-elevációs alcsoportban hasonló adatokra nem számíthatunk, hiszen etikai megfontolások alapján náluk egy randomizált vizsgálat szóba sem jöhet. Pedig e csoport ellátásában is akadhat megfontolnivaló. Emlékeznünk kell arra, hogy az újraélesztést követő kórházi prezentációnak - jóllehet fontos, de mégis - csak egy részkomponense a 12 elvezetéses $\mathrm{EKG}-\mathrm{n}$ látható $\mathrm{ST}$ eleváció, másfelől az ellátás „sikere” nem pusztán a sikeres katéteres intervenció, hanem a beteg lehetőség szerint jó neurológiai állapotban történő hazabocsátása. Az újraélesztés modern korszakában már korán megfogal- mazták a vádat, hogy tevékenységünk egy „iatrogén dementiaepidémiához" vezet, azaz magatehetetlen, ellátásra szoruló betegeket „termelünk” [34]. Ez a jóslat szerencsére nem igazolódott, mégis érdemes azonban minden betegnél megfontolni várható beavatkozásaink hasznát. A kimenetelt befolyásoló egyéb faktorok között természetesen ott vannak a prehospitális ellátás régóta ismert robusztus tényezői, de újabban a beteg kórházi megérkezésekor meghatározható jellemzők jelentőségét is felismerjük.

Nemrégiben amerikai kutatók is egy új, a resuscitatiót követő kedvezőtlen kimenetelt nagyon érzékenyen előjelző egyszerú pontrendszert mutattak be. A „CGRApH" score mindössze 5 tényező alapján ad pontokat, ezek az anamnesztikus koszorúér-betegség, a 11 mmol/l feletti vércukorszint, a nem sokkolható kezdeti ritmus, a 45 évet meghaladó életkor és a 7,0 alatti $\mathrm{pH}$ [35]. Hasonló rendszert francia kutatók is kidolgoztak már. A „Paris Sudden Death Expertise Center” adatbázi-

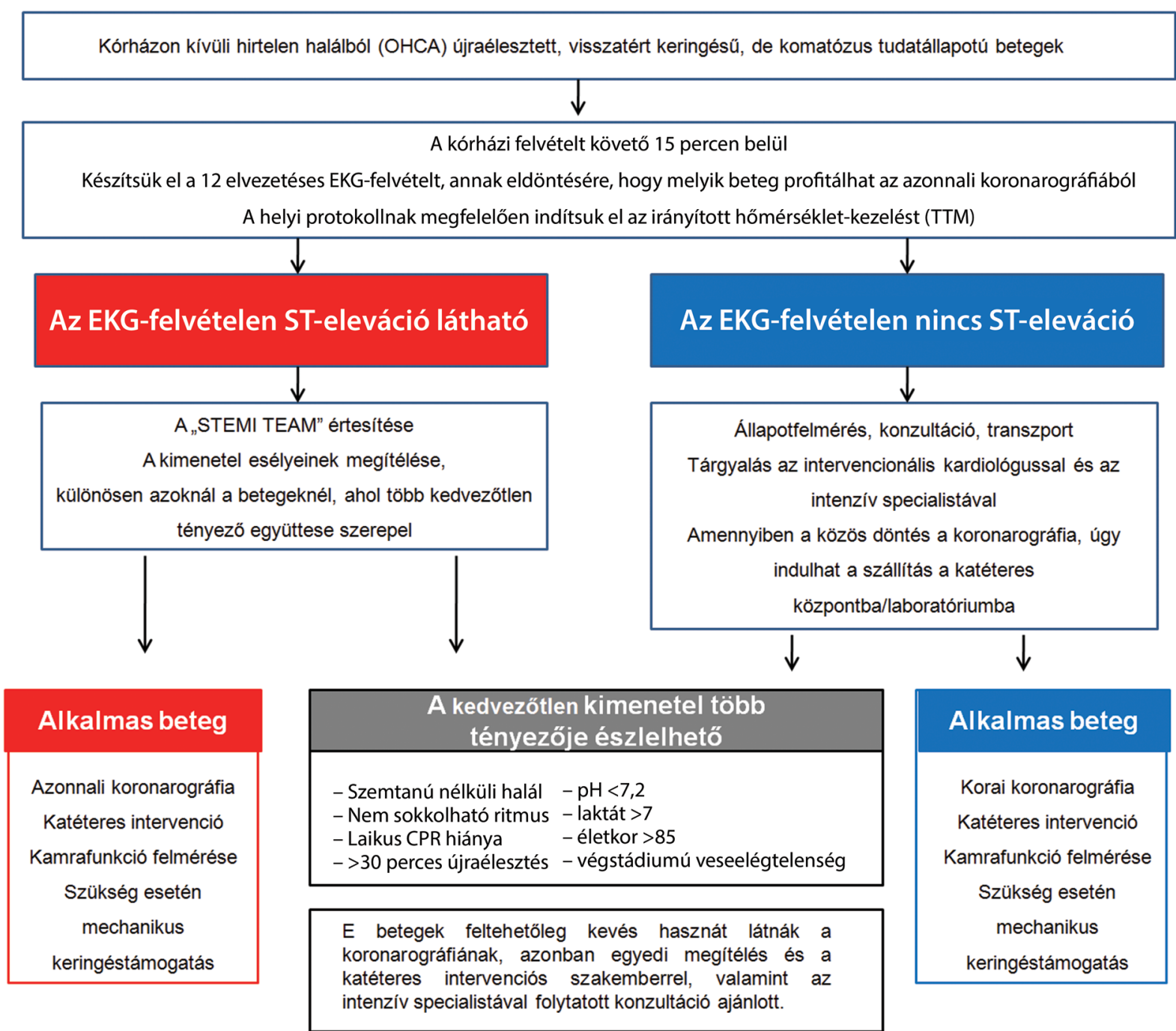

\begin{tabular}{l|l} 
1. ábra & $\begin{array}{l}\text { A resuscitatio komatózus tudatállapotú túlélőinek ellátása az Amerikai Kardiológus Kollégium ajánlása alapján [38 }] \\
\mathrm{CPR}=\text { szív-tüdő újraélesztés; EKG = elektrokardiográfia; OCHA = kórházon kívüli szívmegállás; STEMI = ST-elevációval járó myocardialis infarctus; } \\
\text { TTM = célhőmérséklet-orientált terápia }\end{array}$
\end{tabular} 
sának analízisével megalkottak egy kimenetelt előjelző skálát, a „Cardiac Arrest Hospital Prognosis” (CAHP) pontrendszert [36]. A rendszer a demográfiai adatokra, (nem, életkor), a keringés-összeomlás körülményeit jellemző adatokra (szemtanú jelenléte, laikus újraélesztés, kezdeti sokkolható ritmus), az újraélesztés folyamatának adataira (no-flow és low-flow idők, adrenalindózis) és végül a kórházi felvételnél mért bizonyos laboratóriumi adatokra (pH- és kreatininszint) támaszkodik [36]. A francia CAHP-pontrendszer alkalmazásával Párizs és külvárosainak 2011 és 2015 közötti újtraélesztési adatait vizsgálták meg friss közleményükben Bougouin és mtsai [37]. A CAHP-pontszámok alapján az újraélesztett betegeket alacsony, közepes és nagy kockázatú csoportokba sorolták. A korai CAG aránya az alacsony kockázatú csoportban $86 \%$, a közepes kockázatú csoportban $66 \%$, a nagy kockázatúban pedig mindössze $47 \%$ volt. (Ezek a számok önmagukban arra utalnak, hogy az ellátást végző orvosok diagnosztikus és terápiás döntéseit a kockázat számszerúsítése nélkül is befolyásolhatta a betegeknek a prezentációkor felmért állapota.) A betegek 41\%-ában észleltek ST-elevációt, és a korábbi megfigyelésekkel egybecsengően ezek túlélése (44\%) lényegesen jobb volt, mint a nem ST-elevációs csoporté (27\%). A korai intervenció mindkét csoportban haszonnal járt, azonban azt a figyelemre méltó új megfigyelést tették, hogy a korai intervenció haszna mind az ST-elevációs, mind a nem ST-elevációs alcsoportokban az alacsony CAHP kockázati pontszámú alanyokra korlátozódott. A közepes, illetve magas CAHP kockázati pontszámmal bíró betegeknél a korai CAG/PCI számottevően nem változtatta meg a kimenetelt [37].

Ezek a nagyon elgondolkodtató megfigyelések egybecsengenek a közelmúltban megjelent ajánlásokban megfogalmazott gondolatokkal. Rab és mtsai az Amerikai Kardiológus Kollégium testületének nevében 2015-ben tettek a resuscitatióban részesített kómás túlélők ellátására egy javaslatot, melynek sémáját az 1 ábra mutatja be [38]. Az algoritmusban, bár pontszámok nincsenek hozzájuk rendelve, de az előzőekben bemutatott skálák faktorai köszönnek vissza. Érdemes ezeket a tényezőket mindig megfontolni, mérlegelni. Döntéseink révén gazdálkodunk a rendelkezésre álló erőforrásokkal, de ami még fontosabb, a kilátástalan helyzetben lévő betegek számára biztosíthatjuk a felesleges megpróbáltatásoktól mentes méltóságteljes halál lehetőségét. Ahogy az 1 . ábra is jelzi, a döntés mindig egyedi, s lehetőség szerint élnünk kell a szakemberekkel való konzultáció lehetőségével is.

\section{Appendix}

Kéziratunk lezárását követően került közlésre a cikkünkben is említett COACT-vizsgálat eredménye, melyet az olvasók számára itt röviden ismertetünk [39]. A Hollandia 19 nagy tapasztalatú katéteres intervenciós centruma által folytatott vizsgálatba 552, sokkolható ritmussal ész- lelt, kórházon kívüli hirtelen halált szenvedő beteget vontak be. A bevonási kritériumok alapján csak stabil keringési állapotban lévő alanyok kerülhettek randomizációra. 273 beteget azonnal a katéteres laboratóriumba vittek, s 97\%-ban el is végezték az angiográfiát. A másik szárnyra randomizált 265 beteget intenzív osztályra szállították. Akut kardiológiai indikációval ebben az alcsoportban 38 esetben még az intenzív ápolási időszakban megtörtént a koszorúér-angiográfia. A többieknél erre csak a neurológiai stabilizálódást követően, többnyire az intenzív osztályról való kibocsátáskor (medián 5. napon) került sor. E szárnyon végül összesen 65\%-ban történt meg a vizsgálat. A koronarográfia eltérő gyakorisága nem tükröződött a 90 napos túlélési arányokban; a korai katéteres szárnyon 64,7\%, a késleltetett szárnyon 67,2\% volt, $\mathrm{p}=$ NS. Adná magát a következtetés, hogy a késleltetett katéterezési csoportban azok nem érték meg a koronarográfiát, akik - elsősorban neurológiai károsodásuk miatt - amúgy sem lehettek volna túlélők. Az eredmények értelmezésekor azonban óvatosnak kell lennünk! Mint ahogy arra a cikket kísérő szerkesztői kommentár is rámutat, a vizsgálatot válogatott beteganyagon végezték, Európa egyik legnagyobb katéteres intervenciós hagyományaival bíró fejlett országában. Ez tükröződik a rendkívül magas túlélési arányokban is [40]. Nem tudjuk, hogy más országok gyakorlatában, eltérő betegpopulációban mindez milyen eredményhez vezetne. A további, folyamatban lévő tanulmányok ezekre a kérdésekre is választ fognak adni.

Anyagi támogatás: A közlemény megírása és a kutatás anyagi támogatásban nem részesült.

Szerzôi munkamegosztás: R. L.: Az anyag kidolgozása, szakirodalmi másodelemzés, a kézirat szövegezése. Z. E.: Az anyag kidolgozása, szakirodalmi másodelemzés, a kézirat szövegezése, a végleges kézirat szakmai lektorálása. A cikk végleges változatát a szerzők elolvasták és jóváhagyták.

Érdekeltségek: A szerzőknek a közleményt illetően nincsenek érdekeltségeik.

\section{Irodalom}

[1] Myat A, Song KJ, Rea T. Out-of-hospital cardiac arrest: current concepts. Lancet 2018; 391: 970-979.

[2] Böttiger BW, Van Aken HK. Saving 100,000 lives each year in Europe. Best Pract Res Clin Anaesthesiol. 2013; 27: 291-292.

[3] Nichol G, Soar J. Regional cardiac resuscitation systems of care. Curr Opin Crit Care 2010; 16: 223-230.

[4] Sasson C, Rogers MA, Dahl J, et al. Predictors of survival from out-of-hospital cardiac arrest: a systematic review and meta-analysis. Circ Cardiovasc Outcomes 2010; 3: 63-81.

[5] Daya MR, Schmicker RH, Zive DM, et al. Out-of-hospital cardiac arrest survival improving over time: results from the Resuscitation Outcomes Consortium (ROC). Resuscitation 2015; 91: $108-115$. 
[6] Stub D, Schmicker RH, Anderson ML, et al. Association between hospital post-resuscitative performance and clinical outcomes after out-of-hospital cardiac arrest. Resuscitation 2015; 92: 45-52.

[7] Sidhu SS, Schulman SP, McEvoy JW. Therapeutic hypothermia after cardiac arrest. Curr Treat Options Cardio Med. 2016; 18: 30.

[8] Kok LC, Mitchell MA, Haines DE, et al. Transient ST-elevation after transthoracic cardioversion in patients with hemodynamically unstable ventricular tachyarrhythmia. Am J Cardiol. 2000; 85: 878-881.

[9] Wang K, Asinger RW, Marriott HJ. ST-elevation in conditions other than acute myocardial infarction. N Engl J Med. 2003; 349: 2128-2135.

[10] Cropp GJ, Manning GW. Electrocardiographic changes simulating myocardial ischemia and infarction associated with spontaneous intracranial hemorrhage. Circulation 1960; 22: 25-38.

[11] Dumas F, Cariou A, Manzo-Silberman S, et al. Immediate percutaneous coronary intervention is associated with better survival after out-of-hospital cardiac arrest: insight from the PROCAT (Parisian Region Out of Hospital Cardiac Arrest) registry. Circ Cardiovasc Interv. 2010; 3: 200-207.

[12] Sideris G, Voicu S, Dillinger JG, et al. Value of post-resuscitation electrocardiogram in the diagnosis of acute myocardial infarction in out-of-hospital cardiac arrest patients. Resuscitation 2011; 82: $1148-1153$

[13] Garcia-Tejada J, Jurado-Román A, Rodríguez J, et al. Post resuscitation electrocardiograms, acute coronary findings and in-hospital prognosis of survivors of out-of-hospital cardiac arrest. Resuscitation 2014; 85: 1245-1250.

[14] Kahn JK, Glazier S, Swor R, et al. Primary coronary angioplasty for acute myocardial infarction complicated by out-of-hospital cardiac arrest. Am J Cardiol. 1995; 75: 1069-1070.

[15] Gorjup V, Radsel P, Kocjancic ST, et al. Acute ST-elevation myocardial infarction after successful cardiopulmonary resuscitation. Resuscitation 2007; 72: 379-385.

[16] Nolan JP, Soar J, Cariou A, et al. European Resuscitation Council and European Society of Intensive Care Medicine Guidelines for Post-resuscitation Care 2015. Section 5 of the European Resuscitation Council Guidelines for Resuscitation 2015. Resuscitation 2015; 95: 202-222.

[17] Radsel P, Knafelj R, Kocjancic S, et al. Angiographic characteristics of coronary disease and postresuscitation electrocardiograms in patients with aborted cardiac arrest outside a hospital. Am J Cardiol. 2011; 108: 634-638.

[18] Hollenbeck RD, McPherson JA, Mooney MR, et al. Early cardiac catheterization is associated with improved survival in comatose survivors of cardiac arrest without STEMI. Resuscitation 2014; 85: 88-95.

[19] Kern KB, Lotun K, Patel N, et al. Outcomes of comatose cardiac arrest survivors with and without ST-segment elevation myocardial infarction: importance of coronary angiography. JACC Cardiovasc Interv. 2015; 8: 1031-1040.

[20] Dumas F, Bougouin W, Geri G, et al. Emergency percutaneous coronary intervention in post-cardiac arrest patients without STsegment elevation pattern. Insight from the PROCAT II Registry. JACC Cardiovasc Interv. 2016; 9: 1011-1018.

[21] Elfwén L, Lagedal R, James S, et al. Coronary angiography in out-of-hospital cardiac arrest without ST elevation on ECG short- and long-term survival. Am Heart J. 2018; 200: 90-95.

[22] Millin MG, Comer AC, Nable JV, et al. Patients without ST segment elevation after return of spontaneous circulation may benefit from emergent percutaneous intervention: a systematic review and meta-analysis. Resuscitation 2016; 108: 54-60.

[23] Noc M, Fajadet J, Lassen JF, et al. Invasive coronary treatment strategies for out-of-hospital cardiac arrest: a consensus state- ment from the European Association for Percutaneous Cardiovascular Interventions (EAPCI)/Stent for Life (SFL) groups. Eurointervention 2014; 10: 31-37.

[24] Dankiewicz J, Nielsen N, Annborn M, et al. Survival in patients without acute ST elevation after cardiac arrest and association with early coronary angiography: a post hoc analysis from the TTM trial. Intensive Care Med. 2015; 41: 856-864.

[25] Kleissner M, Sramko M, Kohoutek J, et al. Impact of urgent coronary angiography on mid-term clinical outcome of comatose out-of-hospital cardiac arrest survivors presenting without ST-segment elevation. Resuscitation 2015; 94: 61-66.

[26] Patterson T, Perkins GD, Joseph J, et al. A Randomised tRial of Expedited transfer to a cardiac arrest centre for non-ST elevation ventricular fibrillation out-of-hospital cardiac arrest: the ARREST pilot randomised trial. Resuscitation 2017; 115: 185-191.

[27] Vadeboncoeur TF, Chikani V, Hu C, et al. Association between coronary angiography with or without percutaneous coronary intervention and outcomes after out-of-hospital cardiac arrest. Resuscitation 2018; 127: 21-25.

[28] Lemkes JS, Janssens GN, Straaten HM, et al. Coronary angiography after cardiac arrest: rationale and design of the COACT trial. Am Heart J. 2016; 180: 39-45.

[29] Kern K. Early Coronary Angiography Versus Delayed Coronary Angiography (PEARL). ClinicalTrials.gov Identifier: NCT02387398.

[30] Desch S. Immediate Unselected Coronary Angiography Versus Delayed Triage in Survivors of Out-of-hospital Cardiac Arrest Without ST-segment Elevation (TOMAHAWK). ClinicalTrials. gov Identifier: NCT02750462.

[31] Spaulding C, Hauw-Berlemont C. EMERGEncy Versus Delayed Coronary Angiogram in Survivors of Out-of-hospital Cardiac Arrest (EMERGE). ClinicalTrials.gov Identifier: NCT02876458.

[32] Lagedal R, Elfwén L, James S, et al. Design of DISCO - direct or subacute coronary angiography in out-of-hospital cardiac arrest study. Am Heart J. 2018; 197: 53-61.

[33] Viana-Tejedor A. Coronariography in OUt of hosPital Cardiac arrEst (COUPE). ClinicalTrials.gov Identifier: NCT02641626.

[34] Landau WM. Iatrogenic epidemic involuntary dementia: impending harvest of the cardiopulmonary resuscitation rage. Curr Neurol Neurosci Rep. 2001; 1: 403-404.

[35] Kiehl EL, Parker AM, Matar RM, et al. C-GRApH: a validated scoring system for early stratification of neurologic outcome after out-of-hospital cardiac arrest treated with targeted temperature management. J Am Heart Assoc. 2017; 6: e003821.

[36] Maupain C, Bougouin W, Lamhaut L, et al. The CAHP (Cardiac Arrest Hospital Prognosis) score: a tool for risk stratification after out-of-hospital cardiac arrest. Eur Heart J. 2016; 37: 32223228.

[37] Bougouin W, Dumas F, Karam N, et al. Should we perform an immediate coronary angiogram in all patients after cardiac arrest? Insights from a large French registry. JACC Cardiovasc Interv. 2018; 11: 249-256.

[38] Rab T, Kern KB, Tamis-Holland JE, et al. Cardiac arrest: a treatment algorithm for emergent invasive cardiac procedures in the resuscitated comatose patient. J Am Coll Cardiol. 2015; 66: $62-73$.

[39] Lemkes JS, Janssens GN, van der Hoeven NW, et al. Coronary angiography after cardiac arrest without ST-segment elevation. N Engl J Med. 2019; 380: 1397-1407.

[40] Abella BS, Gaieski DF. Coronary angiography after cardiac arrest - the right timing or the right patients? $\mathrm{N}$ Engl J Med. 2019; 380: 1474-1475

(Rudas László dr., Szeged, Semmelweis u. 6., 6725 e-mail: rudas.laszlo@med.u-szeged.hu)

A cikk a Creative Commons Attribution 4.0 International License (https://creativecommons.org/licenses/by/4.0/) feltételei szerint publikált Open Access közlemény. (SID_1) 